\title{
The development of pupils' Science process skills at secondary school
}

\author{
Peter Demkanin $^{a}$, Lucia Klinovskáb ${ }^{b}$ Peter Horváth \\ ${ }^{a, b, c}$ Comenius University in Bratislava, Faculty of Mathematics, Physics and Informatics, Bratislava,

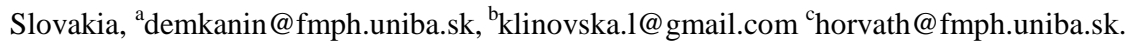

\begin{abstract}
As an integral part of physics education, we consider the development of pupils' SPS. The aim of our survey is the development of selected pupils' SPS - predicting and formulating hypotheses on the age level 14-16 years. As an endeavour to meet such a goal, we prepared and included specific activities, which requires to make predictions or formulate hypotheses, and also we included physics experiments planned by students themselves in physics education. The process of preparation of specific activities for the development of selected SPS is described below. Reason for the inclusion of physics experiment planned by students themselves in physics education is that formulating hypotheses or prediction is one of the planning stages of a physics experiment. In the second part of our contribution, we present our experiences with utilization of specially designed activities and with the implementation physics experiments planned by students themselves. In the last part, we present a Hypotheses quality scale, a tool for the comparison of students' hypotheses, to compare how they formulate hypotheses in the first, second and third activity in a series. We also made a comparison between hypotheses formulated in activities prepared by the teacher and hypotheses formulated for experiments planned by pupils themselves.
\end{abstract}

Keywords: Science process skills, predicting, hypothesis, physics education.

\section{Introduction}

To teach pupils to think is one of the most important goals of schooling. All school subjects should be involved in achieving the goal. In physics lessons, we can achieve it by application of science process skills. 
Harlen (1999) points out that the development of SPS should be the main goal of science education.

\subsection{Predicting and formulating hypotheses}

Predicting is the ability to create a statement about a future event based on a pattern of evidence (Held, 2011). Predictions reflect our understanding of the issue, our experiences, thinking and the evaluation of facts and expected events. Learning predicting is not easy. Students learn to take into account their experience, and they start to think about alternatives. Once the experiment has been completed, it is right to return to the prediction and compare it with reality (Demkanin, 2006; Kireš, 2016).

Quinn and George (1975) define a hypothesis as a testable explanation of an empirical relationship among variables in a given problem situation. Demkanin and Velanová (2016) highlight that a hypothesis is a causal prediction, which must be based on arguments, on previous knowledge. Formulating hypotheses means to make a sentence which includes a verifiable relationship between variables. After verification, we decide if the hypothesis is accepted or not. If we accepted the hypothesis, the predicted relationship between variables is correct. We gained new knowledge. Negative results are as important as positive because they help us cross from ignorance to understanding, but we must continue with researching. Continuing research is based on circumscribed ignorance. If we find that variables are not dependent, our cognition has progressed (Kerlinger, 1972). For example, pupils predicted that a larger area of contact between two surfaces creates a larger frictional force. However, if pupils change the size of surface area, they will found that the frictional force is constant. Pupils gained knowledge about independence of surface area with friction force, their cognition progressed.

Learning hypotheses formation requires to move from the lowest level of creating assumption to the level of making a prediction and then progress to the highest level of formulating hypotheses. If we want to teach pupils to formulate hypotheses of good quality, we must do it gradually. Hypothesis includes predicted relationship between variables. Hypotheses formation requires pupils to be familiar with making correct predictions. Predicting requires to give up guessing and creating assumption. The assessment of the situation, estimate the acquisition of predicting. Correct prediction is not based on guesses, but on a pattern of evidence. Fig. 1 is based on Lapitkova's tables (2015). It schematically shows the progress of teaching hypotheses formation. 
Figure 1 The progress of teaching hypotheses formation

\section{Startinng level - CREATING ASSUMPTION}

- We create situation to say what happen.

- We discuss predictions. Most of the predictions can be disproved - for example if unknown fact appears.

\section{Middle level - PREDICTING}

- The goal is to create a reasoned prediction that describes relationship between variables.

- Hypothesis is based on facts and must be varifiable.

- Progressive development of hypothesis formation - youger pupils formulate hypothesis on their own experience, older pupils used scientific concepts and principles.

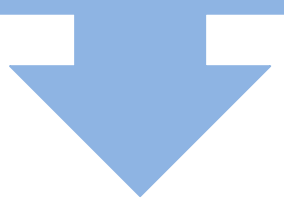

\section{Final level - HYPOTHESIS FORMATION}

Answer on the question: "How to develop selected SPS in the education process?" is still the focus of our research. Withing traditional, instructional education, the task of teachers is to induce situations, which require the application of the skills. We tried to apply this strategy. We focused on the development of predicting and formulating hypotheses on the age level 14-16 years. Our survey took two years. The first year we included in the education process special activities for the development of selected SPS. We prepared 3 activities for the development of formulating hypotheses and some other activities for the development of predicting. The activities for the development of formulating hypotheses were included at the beginning of the school year, in the middle of the school year and at the end of the school year. Activities for the development of predicting were included 
whenever possible. After a few activities aimed at making predictions, students formulated a statement about future event automatically when it was appropriate. After every activity, there was a discussion aimed at making a prediction or hypothesis of good quality.

The process of preparing special activities usually starts by searching for appropriate experiments. We can search in books, magazines or on web sites. Sources of experiments also can be our own ideas or debates with our colleagues, friends and students. Previous methods can inspire us, but generally, this is not enough. The main part of the preparation of activities is to modify them into the form, which offers the opportunity to scaffold students in predicting or in formulating a hypothesis. If we want pupils to predict, we have to challenge them to create a statement about a future event. For example: 'Two same coins are put on the side of a ruler at some distance from each other. What happens when we push one coin, so it hits the other one?" If we want pupils to formulate hypotheses, we have to challenge them to make a sentence which includes a verifiable relationship between variables based on arguments. Jet is an activity aimed at acquisition of pupils' hypotheses. The activity has been included in the education process in the first grade of upper secondary school in part Uneven movement. Pupils have to build a jet whose average velocity is as high as possible. For building and upgrading they could use balloons, straws, twine, paperclips, duct tape, scissors, meter and stopwatch. The most important part of the activity are answers to the question: "How does the average velocity of jet depend on its parameters?" Pupils answered the question before upgrading the jet.

The second year we included in the education process physics experiments planned by pupils themselves. Pupils prepared and performed three physics experiments. In the framework of physical experiments, the pupil has different tasks. One approach to leading pupils to structured work within physical experiments is the approach of the International Baccalaureate Organization. We focused on the planning stage of physics experiments, which contain formulating hypotheses. In the right column is the aspects that pupils and teachers should follow and in the left column is a requirement to fulfil the aspect. 
Table 2 Planning stage of a physics experiment

\begin{tabular}{|c|c|}
\hline $\begin{array}{l}\text { Defining the problem or } \\
\text { research question }\end{array}$ & Identifies a focused problem or research question. \\
\hline $\begin{array}{l}\text { Formulating a hypothesis } \\
\text { or prediction }\end{array}$ & $\begin{array}{l}\text { Relates the hypothesis or prediction directly to the } \\
\text { research question and explains it, quantitatively where } \\
\text { appropriate. }\end{array}$ \\
\hline Selecting variables & $\begin{array}{l}\text { Selects the relevant independent and controlled } \\
\text { variable(s). }\end{array}$ \\
\hline $\begin{array}{l}\text { Selecting } \quad \text { appropriate } \\
\text { apparaturus or materials }\end{array}$ & Selects appropriate apparatus or materials. \\
\hline $\begin{array}{l}\text { Designing a method for } \\
\text { the control of variables }\end{array}$ & $\begin{array}{l}\text { Describes a method that allows for the control of the } \\
\text { variables. }\end{array}$ \\
\hline $\begin{array}{l}\text { Designing a method for } \\
\text { the collection of sufficient } \\
\text { relevant data }\end{array}$ & $\begin{array}{l}\text { Describes a method that allows for the collection of } \\
\text { sufficient relevant data. }\end{array}$ \\
\hline
\end{tabular}

\section{Experiences from implementation specially designed experiments and experiments planned by pupils themselves}

We led pupils to formulate hypothesis before the realization of the experiment. Pupils first formulated hypotheses separately, then discussed their hypotheses with a classmate and then they could change them. When pupils formulate hypotheses first, they were afraid that predicted relationship would not be correct and the hypotheses would not be accepted. We had to encourage them to formulate hypotheses and also we had to assure them that it would not be assessed. Each activity was followed by discussion about their hypothesis. The aim of the discussions was to draw attention to shortcomings of hypotheses to avoid them, and also formulated hypothesis of good quality.

When we first implemented in the education process physics experiments planned by pupils themselves, pupils were confused. Some of them enjoyed that they can explore what they want; others did not know what to do. The most problematic part was to teach students to formulate a problem. We tried to guide them to the clear and correct formulation with appropriate questions. 


\section{The success of pupils' hypothesis formation}

Pupils' hypotheses were evaluated by Hypotheses quality scale, which was created based on Hypotheses quality scale of Quinn and George (1975). Points were assigned to each hypothesis according to the criteria listed in table 3.

Table 3 Hypotheses quality scale

\begin{tabular}{|c|l|}
\hline Points awarded & \multicolumn{1}{c|}{ Criterion } \\
\hline 0 & $\begin{array}{l}\text { No explanation, non-scientific statement, such as, nonsense } \\
\text { statement, a question, an observation. }\end{array}$ \\
\hline 1 & $\begin{array}{l}\text { Partial scientific explanantion, such as, incomplete reference } \\
\text { to variables, a negative explanation or an analogy. }\end{array}$ \\
\hline 2 & $\begin{array}{l}\text { The scientific explanation includes a predictive relationship } \\
\text { between all variables. }\end{array}$ \\
\hline 3 & $\begin{array}{l}\text { The precise explanation includes a predictive relationship } \\
\text { between all variables and a justifying relationship. }\end{array}$ \\
\hline
\end{tabular}

Klinovská, L. (2018)

\subsection{Hypotheses formulated by pupils}

To compare the level of hypothesis formulation, we looked at the percentage of representations of pupils in each points category.

Table 4 Percentage of pupils in individual points' categories

\begin{tabular}{|c|c|c|c|}
\hline & \multicolumn{3}{|c|}{ percentage representation } \\
\hline points awarded & $\begin{array}{c}\text { first hypothesis } \\
\text { formulation }\end{array}$ & $\begin{array}{c}\text { second hypothesis } \\
\text { formulation }\end{array}$ & $\begin{array}{c}\text { third hypothesis } \\
\text { formulation }\end{array}$ \\
\hline 0 & $42 \%$ & $0 \%$ & $9 \%$ \\
\hline 1 & $25 \%$ & $19 \%$ & $64 \%$ \\
\hline 2 & $33 \%$ & $62 \%$ & $9 \%$ \\
\hline 3 & $0 \%$ & $19 \%$ & $18 \%$ \\
\hline
\end{tabular}

Klinovská, L. 
If we look at percentage representation of pupils in individual points' categories in table 4 we see that in the first experiment pupils were afraid to formulate hypotheses- $42 \%$ of pupils did not formulate predicted relationship between variables. The percentage of hypotheses, which contained the relationship between complete variables, almost doubled. In the second and third experiment, some pupils formulated the justified relationship between all variables. They gradually tried to specify the hypotheses.

To compare hypotheses formulated for experiments prepared by us with hypotheses formulated for experiments planned by the students themselves, we looked at percentage representation in individual points' categories. In table 5 we see that almost the same percentage of pupils received 0 points. A significant reduction in the percentage of pupils, who received 1 point reflects the fact that most hypotheses formulated for experiments planned by pupils themselves contain all variables. In the last row of the table we see, that percentage of hypotheses, which include the justified relationship between all variables, doubled. When we looked at the theoretical background, which pupils used in the formulation of their hypotheses, we found out that their arguments were clear and obvious. Based on the results we think that it is easier to argue the relationship between all variables in experiments planned by pupils themselves. These results offer an opportunity to examine whatever the quality of hypotheses is related to the understanding of the problem situation.

Table 5 Percentage representation in individual point's categories for experiments prepared by the teacher and for experiments planned by pupils themselves

\begin{tabular}{|c|c|c|}
\hline & \multicolumn{2}{|c|}{ percentage representation } \\
\hline $\begin{array}{c}\text { points } \\
\text { awarded }\end{array}$ & $\begin{array}{c}\text { experiments } \\
\text { prepared by the } \\
\text { teacher }\end{array}$ & $\begin{array}{c}\text { experiments planned } \\
\text { by pupils themselves }\end{array}$ \\
\hline 0 & $15 \%$ & $16 \%$ \\
\hline 1 & $21 \%$ & $3 \%$ \\
\hline 2 & $54 \%$ & $59 \%$ \\
\hline 3 & $10 \%$ & $22 \%$ \\
\hline \multicolumn{2}{|c|}{ Klinovská, $L}$. \\
\hline
\end{tabular}

\section{Discussion and Conclusion}

In physics lessons, we included 3 specially designed activity aimed at acquisition pupils' hypotheses and 3 physics experiments planned by pupils themselves. Within the limitations of this survey, the observations and percentage representation of pupils in individual points' categories suggest that hypothesis formation can be taught and developed by specially 
designed activities and physics experiments planned by pupils themselves. In the near future, we plan to look at the problem of development of the ability of students to formulate prediction and hypothesis in the light of the learning science (Demkanin, P., 2018). As we know, that formulation of hypothesis most methodologists connect to logical inference abduction, abductive reasoning (Magnani, L., 2017), we plan to analyse each activity used in the process of development of abilities to formulate hypothesis from the view of abduction.

\section{Acknowledgements}

This work has been supported by Scientific Grant Agency of the Ministry of Education under the contract VEGA 1/0273/19, Tutoring and Scaffolding in the Preparation of PreService Physics Teachers

\section{References}

Demkanin, P., \& Velanová, M. (2015). Klúčové tézy obsahu prírodovedného vzdelávania ako kritérium výberu obsahu pre prírodovedné kurikulum. In L. Held (Ed.) Východiská prípravy prírodovedného kurikula pre základnú školu 2020 II (pp. 21- 45). Slovakia, Trnava: Trnavská univerzita.

Demkanin, P., (2018). Concept formation: Physics teacher and his know-how and know-why. In: Jornal of Baltic Science Education, Vol.17,No.1, (pp. 4-7). http://oaji.net/articles/2017/9871519059651.pdf

Demkanin, P., et.al., (2006) Počítačom podporované prírodovedné laboratórium, Bratislava, Comenius University, ISBN:80-989186-10-6,

Held, L. (2011). Výskumne ladená koncepcia prírodovedného vzdelávania. Slovakia, Bratislava: Slovenská akadémia vied.

International Baaccalaurete Organisation, (2001). IB Diploma Programme guide: Physics. Switzerland, Geneva

Kerlinger, F. N. (1972). Základy výzkumu chování - Pedagogický a psychologický výzkum. Czech Republic, Praha: ACADEMIA.

Kireš, M., Ješková, Z., Ganajová, M., \& Kimáková, K. (2016). Bádatel’ské activity v prírodovednom vzdelávaní. Slovakia, Bratislava: štátny pedagogický ústav.

Klinovská, L. (2018). Rozvoj žiackych spôsobilostí vedeckej práce na gymnáziu - master thesis. Slovakia, Bratislava: FMFI UK.

Lapitková, V., Hodosyová, M., Vanyová, M., \& Vnuková, P. (2015). Spôsobilostí vedeckej práce v prírodovednom vzdelávaní. Slovakia, Bratislava: Knižničné a edičné centrum FMFI UK. 
Magnani, L., (2017). The Abductive Structure of Scientific Creativity. Springer, DOI 10.1007/978-3319-59256-5

Lapitková, V., Hodosyová, M., Vanyová, M., \& Vnuková, P. (2015). Spôsobilostí vedeckej práce v prírodovednom vzdelávaní. Slovakia, Bratislava: Knižničné a edičné centrum FMFI UK.

Quinn, M. E., \& George, K. D. (1975). Teaching hypothesis formation, Science Education, 59(3). 289 $-296$. 